\title{
鈍的腎損傷の治療成績と手術適応に関する考察
}

\author{
近畿大学医学部泌尿器科学教室", 近畿大学医学部堺病院泌层器科 \\ NTT 西日本大阪病院泌尿器科 ${ }^{3}$, 近畿大学医学部奈良病院泌尿器科"

\begin{tabular}{|c|c|c|c|c|c|c|}
\hline 健 ${ }^{1)}$ & 能勢 & 和宏 ${ }^{11}$ & 田原 & 秀男 ${ }^{* 1}$ & 原 & \\
\hline 直也 ${ }^{4)}$ & 西岡 & 伯 ${ }^{2)}$ & 江左 & 篤宣 ${ }^{3)}$ & 国方 & 聖司 ${ }^{4)}$ \\
\hline 隆弘 ${ }^{2)}$ & 栗田 & 孝11 & & & & \\
\hline
\end{tabular}

\section{EVALUATION OF THE MANAGEMENT OF BLUNT RENAL TRAUMA AND INDICATION FOR SURGERY} \\ Takeshi Matsuura", Kazuhiro Nose", Hideo Tahara", Yasushi Hara", \\ Naoya Amasaki", ${ }^{4)}$ Tsukasa Nishioka ${ }^{2 \prime}$, Atsunobu Esa ${ }^{3 \prime}$, Seiji Kunikata"), \\ Takahiro Akiyama ${ }^{2)}$ and Takashi Kurita" \\ 'Department of Urology, Kinki University School of Medicine \\ ${ }^{2}$ Department of Urology, Kinki University Sakai Hospital \\ ${ }^{3)}$ Department of Urology, NTT West Osaka Hospital \\ ${ }^{4}$ Department of Urology, Kinki University Nara Hospital
}

(Objectives) Appropriate management of renal trauma is still controversial. Many of the patients have minor injuries and conservative treatment can achieve excellent outcomes without any complications. For major injuries of deep lacerations or ruptures, we have been performing early surgical treatment to salvage the kidney in the selected cases after the precise evaluation of the injury. To obtain the optimal management options, we evaluated the clinical results of our procedures.

(Patients and methods) We conducted a retrospective study, which included 106 cases of blunt renal trauma with evident etiology over the past 22 years and 9 months. The severity of the injury was evaluated mainly by CT scanning. The indication of renal exploration included persistent renal bleeding, large hematoma around the kidney, dislocated fragments, nonviable tissue, massive urinary extravasation and vascular injury. With the patients who required an operation, we first controlled the bleeding by clamping the hilar vessels. Then, the final decision whether to repair or remove the kidney was made based on the direct inspection of the injured kidney after the complete removal of the hematoma. The severity of renal trauma was classified by the classifications found in The Organ Injury Committee of the American Association for the Surgery of Trauma.

(Results) Sixty-three patients were managed conservatively without any interventions, while 22 surgical repairs and 21 nephrectomies were performed. Of the 63 patients, 35 patients $(81.4 \%)$ were operated on within 2 days after the injury. Judging from systolic blood pressure, red cell count, blood loss during surgery and transfusion requirements, surgically treated patients were more severely injured than conservatively treated patients. And nephrectomized patients than surgically repaired patients. All the surgically repaired cases were confirmed to have preserved renal functions postoperatively. In all of the 50 patients with Grade I injuries, conservative treatment was successful. Eight out of the 19 Grade II and III cases, who were indicated for kidney exploration because of multiple lacerations or considerable bleeding, were also successfully repaired. Localized hematoma with no

\footnotetext{
*現 市立堺病院泌尿器科

**現 泉大津市立病院泌尿器科
} 
urine leakage, even when it was large, settled spontaneously without complication. For the 37 Grade IV and V injuries, including 4 cases with hilar injuries, we implemented conservative procedures on 2 patients, surgical repair on 14 patients and nephrectomy on 21 patients. In the conservatively treated cases, one deep laceration with relatively large, but localized, hematoma, and minimal urine extravasation healed spontaneously. Atrophy of the segment and hypertension developed in the other ruptured kidney with dislocated fragments, large hematoma and urine leakage. This kidney, which also required later surgical exploration, did have good parenchymal blood flow. Hilar injury cases were all resulted in nephrectomy.

(Conclusion) In most of our cases the indication for surgical exploration or nephrectomy based on our criteria seemed to be properly decided. Several cases, though, might have received overtreatment. Recent advances in evaluations and strategies of renal trauma have decreased the need for surgical exploration. This may have overreached the indication for conservative management. Severely injured kidneys may be managed conservatively because in most cases bleeding settles after the full formation of large hematoma within the Gerota's fascia. In such cases, though, no one can predict whether the injury will heal spontaneously or not, and, moreover, whether a complication will develop or not. We think that the optimal management of the patient requires an accurate evaluation of the injured kidney. Therefore the indication for surgical exploration should be made based on the degree of the injury.

Key words : blunt renal trauma, management, indication for operation

要旨：(目的) 腎損傷症例の大部分は軽傷で, 保存的治療で合併症なく治癒するが, われわれは中高度損 傷例に対して腎損傷程度診断にもとづき，受傷後早期に手術適応を判断して腎温存を目的とした手術治 療を行ってきた，腎損傷の最適治療法を検討するため，成績を評価するとともに，手術適応について考 察した。

（対象および方法） 22 年 9 力月間に経験した鈍的腎損傷症例 106 例を検討した．手術症例は後腹膜腔 に到達後速やかに腎茎部を遮断し，損傷腎を十分観察して腎修復可能かどうかを判断した.

(結果) 保存的治療を 63 例，手術治療を 43 例（腎修復術 22 例，腎摘除術 21 例）に施行した. I 度損 傷は 50 例全例で保存的治療が可能であった. II, III 度損傷 20 例中 8 例に手術治療を行い, 全例腎温存 が可能であったが多くは保存的治療が可能と思われた. 茎部損傷を含む IV, V 度損傷 37 例では保存的治 療 2 例, 腎修復術 14 例, 腎摘除術 21 例であった. 茎部損傷 4 例は全例腎摘除術を行った。手術治療群 は保存的治療群より, また腎摘除術例は腎修復術例より収縮期血圧, 赤血球数, 術中出血量, 総輸血量 でみると重傷例が多かった，手術適応，腎摘除術適応は適切に決められていたが，一部症例は過剩治療 と思われた。

（結論）腎損傷の治療方針決定には, 画像診断による正確な損傷評価が必須で, 適応症例は早期に手術 を行い, 積極的に腎修復を試みることで腎保存可能な症例を増加させることができると考えた. キーワード：鈍的腎損傷, 治療, 手術適応

\section{緒言}

腎損傷の多くは保存的治療で対処できるが，中等度 ないし高度損傷では治療方針に関する統一見解が得ら れていない. 保存的治療を推奨する報告として, Peterson（1977） ${ }^{11}$ は手術治療を行った症例と比較して保存 的治療で中等度損傷例は機能および形態上から腎温存 が可能であったとし, また, Cheng ら (1994) 21 は保存 的治療で $81 \%$ は後日に外科的治療を必要とせず治瘉 したとしている，一方 Cass ら (1983) ${ }^{3 / 4}$ は，高度損傷 例は自然治癒することはなく, 保存的治療を行った症 例の $30 \%$ は後日何らかの外科的治療を必要とし, 保存
的あるいは外科的治療で腎喪失率は同程度であったこ とからむしろ手術治療を勧めている．また，治療法に 関する意見が混乱しているのは損傷の評価分類法が十 分でないとの指摘もある ${ }^{5}$. われわれは, 保存的治療後 の合併症発症例に対し手術治療を試みるも, 高度癒着 のため満足な手術を施行できなかった数例の経験か ら, 中高度損傷例に対しては, 実質損傷, 血腫, 尿溢 流，腎血流の状態を考慮の上，受傷後早期に適応を判 断して腎温存を目的とした手術治療を積極的に施行し てきたので，保存的治療を行った症例と比較して成績 を評価した。 


\section{対象・方法}

1977 年 4 月より 1999 年 12 月までに 109 例の腎損 傷症例を経験したが，このうち医原性および受傷機転 不明の 3 例を除外した 106 例を検討対象とし, 診療録, レントゲンフィルムを調查した．男性 82 例，女性 24 例で，年齢は 20 歳 (2 88)（中央值，範囲，以下同じ) であった，全例鈍的外傷で，受傷原因は，交通事故 55 例, スポーツ外傷 17 例, 労働災害 5 例のほか, 打撲 17 例，転落 12 例であった。病的腎の合併は腎囊胞 5 例, 腎孟尿管移行部狭窄症 4 例, 馬蹄鉄腎 1 例で, 対側に 先天性低形成腎 1 例が認められた。

全身状態, 他臓器合併損傷, 諸検査成績, 画像診断 結果で治療方針を決定し，画像診断上高度の腎実質断 裂，腎周囲血腫，尿溢流，無血流離断片を認める場合 早期手術を行った. 106 例のうち保存的治療 63 例，手 術治療 43 例（腎修復術 22 例，腎摘除術 21 例）であっ た。保存的治療は安静, 輸液, 輸血を行い, 動脈塞栓 術，経皮的ドレナージ，尿管ステント留置を行った症 例はなかった。また腎修復術は全例開放手術を行った 症例で，腎盘，腎実質縫合術，離断片摘除などの腎部 分切除術も含む. 手術症例のうち 35 例 $(81.4 \%)$ は受 傷後 2 日以内に手術を行った。腎への到達法は経腰的 23 例, 経腹的 20 例で, 到達経路の如何にかかわらず, 先ず腎筋膜を十分広く露呈した後，これを大きく切開 して用手的に速やかに腎菱部へ到達し，手指圧迫ある いは続いてゴム付き腎鉗子をかけ出血をコントロール
した。腎周囲は血腫によりすでに剥離されている状態 のため，腎血流遮断は比較的容易に極めて短時間で行 えることが多い. 血腫を除去後損傷腎を十分観察して, 修復可能かどうかを判断し手術方針を決定した。

腎損傷の分類は The Organ Injury Committee（O.I S.) of the American Association for the Surgery of Trauma (A.A.S.T.)．分類 ${ }^{6}$ にもとづき，統計量検定は Mann-Whitney U 検定あるいはカイ 2 乗検定を行っ た.

当院の腎損傷に対する救急医療体制は, 1982 年 5 月 の救命救急七ンター開設前後で少し異なっている. 開 設前は，当科で直接治療依頼を受け，12 例（保存的治 療 6 例：I 度 5 例, II 度 1 例, 手術治療 6 例：III 度 1 例，IV 度 4 例，V 度 1 例）を治療した．開設後は救命 救急センターへ搬送された後，腎損傷の治療に関し当 科へ 94 例（保存的治療 57 例：I 度 45 例, II 度 3 例, III 度 7 例, IV 度 2 例, 手術治療 37 例：II 度 2 例, III 度 5 例, IV 度 21 例, V 度 9 例) のコンサルテーション があった．多発外傷例は他科との共観症例として，腎 損傷が主外傷例は主科として，軽傷例など一部の例外 を除き, 泌尿器科医がほとんど全例で治療方針の決定, 手術に参加した。

\section{結 果}

1. 受診時症状, 検査值（表 1)

受傷後は血尿を来すことがほとんどで, 軽傷例でも 受診の契機となる事が多い，反対に，高度損傷例でも

表 1 受診時症状, 検査值

\begin{tabular}{|c|c|c|c|}
\hline 腎損傷症例 & $\begin{array}{c}\text { 保存的治療 } \\
N=63\end{array}$ & $\begin{array}{c}\text { 手術治療 } \\
\mathrm{N}=43\end{array}$ & $\mathrm{p}$ \\
\hline $\begin{array}{l}\text { 受診までの日数(日) } \\
\text { 中央值 (範囲) }\end{array}$ & $1.0(0 \sim 89)$ & $0(0 \sim 23)$ & 0.0453 \\
\hline $\begin{array}{l}\text { 受傷側 } \\
\text { 右 / 左 / 不明 }\end{array}$ & $16 / 46 / 1$ & $23 / 20 / 0$ & 0.0108 \\
\hline $\begin{array}{l}\text { 血尿 (例) } \\
\text { 肉眼的 } \\
\text { 顕微鏡的 } \\
\text { なし } \\
\text { 不明 }\end{array}$ & $\begin{array}{c}49 \\
9 \\
4 \\
1\end{array}$ & $\begin{array}{c}37 \\
2 \\
3 \\
1\end{array}$ & 0.4592 \\
\hline $\begin{array}{c}\text { 収縮期血圧 (mmHg) } \\
\text { 中央值 (範囲) }\end{array}$ & $120(92 \sim 168)$ & $108(45 \sim 148)$ & 0.0003 \\
\hline 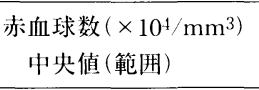 & $430(215 \sim 556)$ & $387(180 \sim 507)$ & 0.0002 \\
\hline $\begin{array}{c}\text { 他臟器損傷 } \\
\text { あり/なし }\end{array}$ & $18 / 45$ & $18 / 25$ & 0.1560 \\
\hline
\end{tabular}


表 2 最終診断

\begin{tabular}{c|c|c|c}
\hline \multirow{2}{*}{$\begin{array}{c}\text { AAST 分類* } \\
\text { Grade }\end{array}$} & \multirow{2}{*}{$\begin{array}{c}\text { 保存的治療 } \\
\text { (例) }\end{array}$} & \multicolumn{2}{|c}{ 手術治療(例) } \\
\cline { 3 - 4 } & & 腎修復術 & 腎摘除術 \\
\hline I & 50 & 0 & 0 \\
II & 4 & 2 & 0 \\
III & 7 & $6 * *$ & 0 \\
IV & 2 & 14 & 11 \\
V & 0 & 0 & 10 \\
\hline 計 & 63 例 & 22 例 & 21 例 \\
\hline
\end{tabular}

*: The Organ Injury Scaling(O.I.S.) Committee of the American Association for the Surgery of Trauma(A.A.S.T.) Grade I, microscopic or gross hematuria ; normal urologic studies ; subcapsular, nonexpanding hematoma without parenchymal laceration. Grade II, nonexpanding, perirenal hematoma confined to renal retroperitoneum ; laceration $<1$ $\mathrm{cm}$ parenchymal depth of renal cortex without urinary extravasation. Grade III, laceration $>1 \mathrm{~cm}$ parenchymal depth of renal cortex without collecting system rupture or urinary extravasation. Grade $N$, parenchymal laceration extending through the renal cortex, medulla and collecting system ; main renal artery or vein injury with contained hemorrhage. Grade V, completely shattered kidney ; avulsion of renal hilum which devascularizes kidney.

**：1 例で血腫除去, ドレナージ術のみ施行

血尿がみられないこともあり，腎動脈閉塞例は血尿を 来さなかった，収縮期血圧は保存的治療群と比較して 手術治療群で有意に低く, ショック症状 $(90 \mathrm{mmHg}$ 以下) を認めた症例は保存的治療群 3 例 (4.8\%), 手術 治療群 22 例 $(48.8 \%)(\mathrm{p}=0.0001)$ であった.さらに, 手術治療群のうち腎修復術例は $116 \mathrm{mmHg}(54 \sim 148)$, 腎摘除術例は $98 \mathrm{mmHg}(45 \sim 136)(\mathrm{p}=0.053)$ であっ た. 赤血球数も手術治療群で有意に低值で, 腎修復術 例 $412 \times 10^{4} / \mathrm{mm}^{3}(201 \sim 507)$ ，腎摘除術例 $366 \times 10^{4} /$

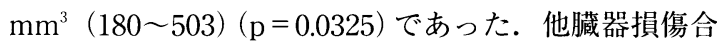
併例は，それぞれ 18 例づつ認め, 手術治療を要したの は保存的治療群 4 例 (6.3\%, 肝, 脾損傷), 手術治療群 8 例（18.6\%，肝，脾損傷，消化管損傷，骨盤骨折）で あった。

\section{2. 最終診断}

画像診断および手術治療群では術中所見にもとづく 最終診断を表 2 に示す. I 度損傷は 50 例全例で保存的 治療が可能であった. II, III 度損傷では 19 例中 8 例に 手術治療を行ったが, 全例で腎温存手術が可能であっ た. 腎茎部血管損傷 4 例を含む IV, $\mathrm{V}$ 度損傷例では手 術施行例が 35 例を占め 14 例で腎修復術を行った。保
存的治療を行ったのは IV 度損傷の 2 例のみで, 1 例 は，CT 上血腫は腎全周性に認められたが腎実質前後 径の約半分の厚さで，尿溢流も限局性であった．血腫 は 6 力月後には完全に吸収され, 3 年後も血圧, 腎機能 は正常であった．他の 1 例は他院で保存的治療を受け 2 力月後に当科へ紹介された．血管造影で腎は上下に 2 分されていたが血流は比較的よく保たれていたため そのまま保存的に治療した。しかし， 2 年後に高血圧 (170/80mmHg) を発症し，血漿レニン活性（PRA）は 末梢 $4.9 \mathrm{ng} / \mathrm{ml} / \mathrm{h}$ （左/右 $=5.8 / 2.4 ）$ と上昇した. CT 所見で腎下半部は十分な血流を認めたが，上半部は血 流をほとんど認めず萎縮し, 受傷後 3 年 6 力月で手術 を行った，高度癒着のため手術は極めて困難で腎上半 の部分切除術を施行したが, 術後残存下半部は無機能 腎となり，血圧は 130/88mmHg と正常化した. 腎茎部 損傷例は全例腎摘除術になった。

3. 入院中，退院後経過（表 3)

前医で輸血，輸液など治療を受けている症例もある ため正確なことは言えないが，当科入院後に進行性の 赤血球数低下を来した症例あるいは循環状態維持のた め積極的な輸血を要した症例は保存的治療群ではみら れなかった，手術治療群では 9 例あり，いずれも受傷 後 12 時間以内に受診あるいは搬入された症例であっ た.これに対し，受傷 12 時間以上で入院した症例では みられなかった。

総輸血量は手術治療群が保存的治療群より有意に多 かった。手術治療群を腎修復術症例と腎摘除術症例に 分けて検討すると, 総輸血量はそれぞれ $0 \mathrm{ml}(0$ ～ $7,740$, 平均値 $1,445.9 \mathrm{ml}), 1,620 \mathrm{ml}(0 \sim 12,790$, 平均值 $3,158.6 \mathrm{ml})(\mathrm{p}=0.0029)$, 術中出血量は $525 \mathrm{ml}(74$ $5,760$, 平均值 $1,134.9 \mathrm{ml}), 1,500 \mathrm{ml}(663 \sim 11,392$, 平均值 2,299.8ml）（p=0.0022）であった．入院中の合併症は手 術治療群で 7 例みられ，急性腎不全 1 例（一時的に血 液透析を要した), 遅発性小腸穿孔 1 例 (手術を要した) 以外の肝炎 1 例, 血尿 1 例, 多血症 1 例, 後腹膜出血 2 例は軽度のものであった，退院後十分な経過観察が できている症例は特に保存的治療群で少なく, 合併症 の十分な検討は不可能であった，腎修復術を行った症 例は，全例で画像上温存腎の機能を確認できた．検討 症例で腎損傷に関連した重大な合併症はみられなかっ たが，保存的治療群の 1 例が慢性腎炎のため受傷 7 年 後に血液透析を導入された。また手術治療群で腎損傷 による腎摘除術既往例の交通外傷による対側腎損傷を 経験した。腎茥部動脈損傷，粉砕破裂例で腎摘除術を 
表 3 入院中, 退院後経過

\begin{tabular}{|c|c|c|c|}
\hline 経過 & 保存的治療 & 手術治療 & $\mathrm{p}$ \\
\hline $\begin{array}{c}\text { 入院後進行性出血 * (例) } \\
\text { あり/なし }\end{array}$ & $0 / 63$ & $9 / 34$ & 0.0006 \\
\hline $\begin{array}{l}\text { 総輸血量 }(\mathrm{ml}) \\
\text { 中央値 }(\text { 範囲) }\end{array}$ & $0(0 \sim 4,680)$ & $1.400(0 \sim 12.790)$ & $<0.0001$ \\
\hline $\begin{array}{c}\text { 入院中合併症(例) } \\
\text { あり/なし }\end{array}$ & $0 / 63$ & $7 / 36$ & \\
\hline $\begin{array}{l}\text { 入院日数 (日) } \\
\text { 中央値 (範囲) }\end{array}$ & $14(1 \sim 52)$ & $25(10 \sim 139)$ & $<0.0001$ \\
\hline $\begin{array}{l}\text { 観察期間 (日) } \\
\text { 中央値 (範囲) }\end{array}$ & $40(2 \sim 3,615)$ & $218(12 \sim 4,656)$ & 0.0013 \\
\hline $\begin{array}{c}\text { 退院後合併症* (例) } \\
\text { あり/なし/不明 }\end{array}$ & $2 / 13 / 48$ & $2 / 22 / 19$ & \\
\hline $\begin{array}{c}\mathrm{s}-\mathrm{Cr}, \text { 尿蛋白異常**(例) } \\
\text { あり/なし/不明 }\end{array}$ & $0 / 15 / 48$ & $2 / 23 / 18$ & \\
\hline
\end{tabular}

* : 赤血球数低下 $\left(>50 \times 10^{4} / \mathrm{mm}^{3} / 24 \mathrm{~h}\right)$ または術前輸血 $(>1,000 \mathrm{ml})$ を要した症例 (Grade III 1 例, Grade IV 5 例, Grade V 3 例)

**:6 力月以上経過観察症例

余儀なくされたため, 血液透析導入後腎移植を行った.

\section{考察}

腎損傷の治療目的は合併症（特に高血圧）を発症さ せることなく損傷腎の実質（ネフロン）を可能な限り 温存することと考えられる．腎損傷例の多くは軽傷で 保存的治療の適応となり, 中高度損傷でも腎筋膜内に 血腫を形成し，内圧が上昇すると自然止血するため, 十分な輸血，輸液で全身状態が安定すればそのまま保 存的に治療される傾向が強くなっているように思われ る.この理由として, 短期的には合併症の多い可能性 があるが，腎を温存できる可能性が高く，高血圧発症 の頻度も実際には低值であることがあげられてい る .一一方, 持続性出血は手術の絶対適応とされ, 相対 適応として, 高度の無血流離断片, 尿溢流, 腎血管損 傷，また損傷評価が十分できないときがあげられてい $3^{899}$. 実際の臨床現場では治療法の選択に迷うことも 多いが，われわれの施設では初期の症例で手術を行う 症例が多かったなど，時期により手術適応に多少の差 異があるものの, 腎実質損傷程度で手術適応を判断し， 適応例には積極的に腎温存を目的とした受傷後早期の 手術治療を行ってきた ${ }^{10}$ ．今回の検討を終えた後，経 皮的処置などを否定するつもりはないが，当初われわ れが治療法として採用しなかったのは次の理由によ る．腎が損傷されると腎筋膜内に出血が起こるが，血
腫は比較的早期に完成されるのではないかと考えた。 われわれの検討で (表 3 ), 入院後も持続性出血が考え られたのは手術治療群のうち受傷後早期に受診した III 度損傷 1 例, IV 度損傷 5 例, $\mathrm{V}$ 度損傷 3 例でその他 の症例では受診時には血腫がほぼ完成されていた可能 性が高いと考えられる，従って，動脈塞栓術の適応は 限定されたものになると思われ，持続性出血例はむし ろ手術適応と考えた，また，経皮ドレナージで血腫を 直ちに完全除去することは不可能で，むしろ尿漏のド レナージを目的とするが，高度損傷例にはむしろ腎修 復術で損傷面の接着を図り，創傷治癒を促す方がよい のではないか，また，ある程度の血腫は無処置で吸収 される可能性が高いのではないかと考えた.

今回の集計で，手術治療を行った症例が他の報告よ り多かったので8.9111, 手術治療を選択した理由を詳し く検討したＩII，III 度損傷 8 例で手術治療を選択した 理由を表 4 に示す. 血腫が大きい症例, 循環状態が安 定しない症例, 感染を併発した症例などが含まれるが, 後方視的にはこれらのうち多くの症例は無処置で，あ るいは経皮的血腫ドレナージ，選択的動脈塞栓術など を併用した保存的治療が可能であったと思われる（表 $4: *)$. しかし, III 度損傷でも腎実質損傷程度に比較 して, 出血が多い症例を認め, われわれも収縮期血圧, 赤血球数がそれぞれ $54 \mathrm{mmHg}, 304 \times 10^{4} / \mathrm{mm}^{3}$ また 50 
表 4 手術症例

\begin{tabular}{|c|c|}
\hline 手術治療施行理由 & 症例数 (例) \\
\hline $\begin{array}{l}\text { Grade II, III 症例腎修復術施行理由 } \\
\text { 循環虚脱 (ショック) } \\
\text { 多発表在性裂傷 } \\
\text { 他院保存的治療後発熱 } \\
\text { 他臟器手術 } \\
\text { 損傷過大評価 }\end{array}$ & $\begin{array}{l}(8 \text { 例) } \\
2^{*} \\
3^{*} \\
1 \\
1 \\
1^{*}\end{array}$ \\
\hline $\begin{array}{l}\text { Grade IV, V 症例腎摘除術施行理由 } \\
\text { 腎血管離断 } \\
\text { 血流不良 } \\
\text { 腎動脈閉塞 } \\
\text { 区域動脈損傷 } \\
\text { 粉砕破裂 } \\
\text { 修復不能 } \\
\text { 多発深在性裂傷, 離断 } \\
\text { 血管, 腎盂が別の離断片に付着 } \\
\text { 粉砕破裂 } \\
\text { 他臓器手術時循環不安定 }\end{array}$ & $\begin{array}{ll}(21 \text { 例) } \\
2 & \\
8 & \\
& 2 \\
& 2 * * \\
& 4 \\
10 & \\
& \\
& 3 * * \\
& 3 \\
& 4 \\
1 * * & \end{array}$ \\
\hline
\end{tabular}

$\mathrm{mmHg}, 201 \times 10^{4} / \mathrm{mm}^{3}$ まで低下した 2 例を経験し, 保 存的治療を行うときは注意が必要で，場合により手術 治療を要することもあると考える。また， IV , V 度損 傷例で腎摘除術を行った症例が 21 例あり, 術中の術者 判断による腎摘理由を表 4 に示す。いずれも高度損傷 例で, 腎血管, 腎孟の腎離断片への付着状況など, 術 中に初めて正確な損傷診断ができた症例もあり，この ような症例は保存的治療で腎摘除を免れても腎機能予 後から見た治癒は望めなかったと思われる，手術適応 はほぼ適正に判断されていたと考えるが, 術前画像診 断, 手術所見から腎の一部が温存可能であったかも知 れないと思われる症例も認めた (表 $4 ： * *$ )。また, IV 度損傷例で腎修復術を行った 14 例のうち 5 例は, 実質損傷, 血腫, 尿溢流の程度から判断すると, 保存 的治療が可能であったかも知れない. 手術をすること で腎摘除が多くなるという理由で保存的治療を勧める 報告 ${ }^{22}$ があるが, 今回の検討で, 術中出血量, 輸血量を みても腎摘例は重傷例が多く腎損傷程度が強いため腎 摘除術が施行されたと考える ${ }^{131}$. また，腎損傷の手術 では, 最初に出血をコントロールする必要があるため, Treitz 䩲带部で大動脈前面から腎血管を剥離する方

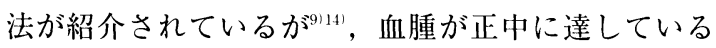
場合は血腫の中を剥離することになり，かえって手間 取ることになりかねず, 慣れた到達法でよいと考える.
腎損傷例に若年者が多いことから，治療成績の評価 では腎機能予後, 合併症の検討が重要である.しかし, 長期に十分に経過観察した症例で検討した報告はほと んどなく，今回の検討でも特に保存的治療群では軽傷 例が多いことから，十分に経過観察されているとは言 い難い。また，腎が両側性臓器であることから，われ われの症例も含め, 総腎機能が問題になることは少な いが，可能な限り腎実質温存を目標にした治療を行う べきである．腎損傷後高血圧の発生頻度は約 $5.2 \%$ と され ${ }^{(5)}$, 原因として, 腎動脈および分枝の閉塞, 腎動静 脈瘦形成 (穿通性損傷), Page 腎などがあげられる。わ れわれの腎動脈損傷例はすべて腎摘除術となったが, 積極的に血流再開を試みている報告もある(1)1 - 18). 高 血圧発症が保存的治療で $50 \%$ に達するという報告が あり ${ }^{191}$ ，高血圧を発症しなくても通常は萎縮腎となる ため $\left.{ }^{17}\right)^{\prime}$ 価すべき試みであるが，実際の成功率は高く なく, 他臓器損傷合併例など重傷例が多いことから, 血流再開術の適応は若年者の両側損傷例などに限られ ると思われる．また最近では血管内ステントによる治 療も試みられている ${ }^{201}$. 腎損傷後の Page 腎に関して も, 頻度が少ない原因として短期間の観察しかなされ ていないことが指摘されている ${ }^{15)}$. 反対に, Page 腎の 原因として, 腎損傷が重要とされ, 貯留液の穿刺吸引 のみあるいは 1 年以上経過してからの手術では高血圧 が治癒しにくく腎摘除術が必要と言われ ${ }^{15 \cdot 211}$, 初期治 療法選択の重要性を示唆している.

われわれは，腎損傷の治療方針決定に際し，損傷程 度により手術適応を判断することが重要と考えてい る.一般に損傷評価に CT が有用とされて22!，われわれ も単純 CT および造影 CT (早期像, 後期像), CT 後の 腹部単純撮影でかなり正確な損傷評価が可能と考えて いる.

保存的治療の可能限界を判断することはかなり困難 であるが, 今回検討した保存的治療群の比較的高度損 傷例のうち，腎実質損傷が明らかでも，離断片の大き な解離がなく, 尿溢流は限局性で, 全周性血腫があっ ても厚さが腎実質前後径の半分程度の症例は併用処置 を要さず合併症なく治癒を確認できた。また，血腫が 腎実質前後径程度あるいはもう少し大きくても, 全周 性でなく上極, 後面, 下極に限局し, 前面には存在し なかった症例も, 併用処置を行うことなく血腫は吸収 され, 合併症も発症しなかった。一方, 離断片の解離 があり, 全周性の大きい血腫, 高度の尿溢流を認めた 症例は，血管造影で比較的良好に血流が保たれていた 
にもかかわらず後日離断片の機能が廃絶し高血圧をき たした，以上より，IV 度損傷例で全周性の大血腫，離 断片の解離, 高度の尿溢流は手術適応の指標と考えて よいと思われる. 無血流離断片も膿瘍, 感染性尿貯留 腫, 後出血などの合併症が多いため, 手術による debridement がよいとされる ${ }^{23}$. IV, $\mathrm{V}$ 度損傷例の一部 は保存的治療の有効性が報告され ${ }^{2,24}$, 併用処置が有 効な場合もあると考えられる，尿管ステント留置は受 傷後早期に適応を考慮すべきであるが，膀胱尿管逆流 が必発であることを銘記する必要がある．経皮ドレ ナージは保存的治療例の経過観察中にその適応, 時期 を判断すべきと考えている，高度の尿溢流は腎杯，腎 孟の高度損傷を示し，大きい血腫を伴うことも多いた め, 高度の癒着, 線維化をきたす可能性が高いと思わ れる. 従って, 手術を考える場合は癒着の生じない受 傷後数日以内に行うべきと考える．外科手術の創傷治 癒理論上も, 瘷痕組織の質と量すなわち損傷後の治癒 過程で産生された膠原線維の改築状態が重要で251, 組 織の適切な接着すなわち正確な縫合が基本にあると考 えられる，また，手術を決定した場合は，腎保存手術 を先ず考慮すべきで，そのつもりで手術に臨むことに より，従来腎摘除術となった損傷例でも，腎温存可能 な症例を増加させることができると思われる。また， 術中所見で腎修復がどうしても不可能な症例は腎摘除 すべきと考えるが，ベンチサージェリーによる修復， 自家腎移植の適応も考慮すべきかも知れない.

鈍的腎損傷の治療方針は多くの意見があり, 特に IV 度損傷例で意見の分かれるところである. 併用処置も 考慮しない保存的治療を行うのか, 経皮ドレナージ, 動脈塞栓術を考慮するのか，あるいは手術による腎修 復を目指すのか, 最良の治療法に関する結論は多施設 の多数症例による長期的研究を待たなければならな い.

\section{結語}

腎損傷症例で保存的治療, 手術治療の成績を評価し われわれの腎損傷に対する治療方針を述べた，手術適 応はほぼ適切に決められていたが，実際にはやや過剒 手術と考えられる症例も認めた．腎損傷の大部分は保 存的治療の適応と考えるが, 最近は重傷例でも保存的 に治療される傾向が強いように思われる.われわれは, これにやや批判的な意見を持ち, 腎損傷の治療法は腎 損傷程度にもとづいて決定されるべきと考える，手術 を決定した症例には，正確，迅速な手技のもと，可能 な限り腎温存を心がけなければならない。
われわれの経験による保存的治療の可能限界，手術 適応基準は考察中に記したつもりであるが，実際の症 例を前にして一律には決められないと思われる.また， 本論文は決して手術治療を萀めているのではないが, 手術適応の積極的な選択が必要な症例も多いと考え る.

本論文の要旨は, 第 43 回日本腎臟学会総会（平成 12 年 5 月, 名古屋) および第 88 回日本泌尿器科学会総会（平成 12 年 6 月，札幌）で発表した。

貴重な腎損傷症例を多数例ご紹介いただいた，当院救命 救急七ンター坂田育弘教授はじめスタッフの諸先生方に深 く感謝いたします。

\section{文献}

1) Peterson, N.E. : Intermediate-degree blunt renal trauma. J. Trauma, 17, 425-435, 1977.

2) Chang, D.L-W., Lazen, D. and Stone, N. : Conservative treatment of type III renal trauma. J. Trauma, 36, 491-494, 1994.

3) Cass, A.S. and Luxenberg, M. : Conservative or immediate surgical management of blunt renal injuries. J. Urol., 130, 11-16, 1983.

4) Cass, A.S. and Cass, B.P. : Immediate surgical management of severe renal injuries in multipleinjured patients. Urology, 21, 140-145, 1983.

5) Lent, V.: What classification is appropriate in renal trauma?. Eur. Urol., 30, 327-334, 1996.

6) Moore, E.E., Shackford, S.R., Pachter, H.L., McAninch.J.W., Browner, B.D., Champion, H.R., Flint, L. M., Gennarelli, T.A., Malangoni, M.A., Ramenofsky, M.L. and Trafton, P.G. : Organ injury scaling : spleen, liver, kidney. J. Trauma, 29, 1664-1666, 1989.

7) Goldman, S.M. and Sandler, C.M. : Upper urinary tract trauma-current concepts. World J. Urol., 16, $62-68,1998$.

8) Meng, M.V., Brandes, S.B. and McAninch, J.W. : Renal trauma : indications and techniques for surgical exploration. World J. Urol., 17, 71-77, 1999.

9) Morey, S.F. and McAninch, J.W. : Renal trauma. In Glenn's Urologic Surgery, 5th ed., p 117-121, Lippincott-Raven Publishers, Philadelphia, 1998.

10）松浦 健, 栗田 孝: 腎外傷の診断と手術適応. 救 急医学, 9, 305-313, 1985.

11）飯山達雄, 阪倉直樹, 山崎一郎, 山本志雄, 北村龍 彦，井上啓史：腎外傷の臨床的検討一損傷程度 · 合併症による治療方針の決定. 西日泌尿, 61, 564568,1999 .

12) Robert, M., Drianno, N., Muir, G., Delbos, O. and Guiter, J. : Management of major blunt renal lac- 
erations : surgical or nonoperative approach? Eur. Urol., 30, 335-339, 1996.

13) Nash, P.A., Bruce, J.E. and McAninch, J.W. : Nephrectomy for traumatic renal injuries. J. Urol., 153, 609-611, 1995.

14) Carroll, P.R., Klosterman, P. and McAninch, J.W. : Early vascular control for renal trauma : a critical review. J. Urol., 141, 826-829, 1989.

15) Watts, R.A. and Hoffbrand, B.I. : Hypertension following renal trauma. J. Hum. Hypertens., 1, 65$71,1987$.

16) Cass, A.S., Bubrick, M., Luxenberg, M., Gleich, P. and Smith, C.: Renal pedicle injury in patients with multiple injuries. J. Trauma, 25, 892-896, 1985.

17) Clark, D.E., Georgitis, J.W. and Ray, F.S. : Renal arterial injuries caused by blunt trauma. Surgery, 90, 87-96, 1981.

18) Haas, C.A.. Dinchman, K.H., Nasrallah, P.F. and Spirnak, J.P. : Traumatic renal artery occlusion : a 15-year review. J. Trauma, 45, 557-561, 1998.

19) Stables, D.P., Fouche, R.F., de Villiers van Niekerk, J.P., Cremin, B.J., Holt, S.A. and Peterson, N.E. : Traumatic renal artery occlusion : 21 cases. J. Urol., 115, 229-233, 1976.

20) Goodman, D.N., Saibil, E.A. and Kodama, R.T. :
Traumatic intimal tear of the renal artery treated by insertion of a Palmaz stent. Cardiovasc. Intervent. Radiol., 21, 69-72, 1998.

21) Sterns, R.H., Rabinowitz, R., Segal, A.J. and Spitzer, R.M. : "Page kidney" Hypertension caused by chronic subcapsular hematoma. Arch. Intern. Med., 145, 169-172, 1985.

22) Iguchi, Y., Takaki, N., Nakamura, K., Sato, S. Kato, A, Matsuo, Y., Kudo, S. and Masaki, Z. : Significance of hematoma size for evaluating the grade of blunt renal trauma. Int. J. Urol., 6, 502-508, 1999.

23) Husmann, D.A. and Morris, J.S. : Attempted nonoperative management of blunt renal lacerations extending through the corticomedullary junction : the short-term and long-term sequelae. J. Urol., 143, $682-684,1990$

24) Altman, A.L., Haas, C., Dinchman, K.H. and Spirnak, J.P. : Selective nonoperative management of blunt grade 5 renal injury. J. Urol., 164, 27-31. 2000.

25) Deodhar, A.K. and Rana, R.E. : Surgical physiology of wound healing : a review. J. Postgrad. Med., 43. $52-56,1997$.

(2000 年 10 月 20 日受付, 2001 年 11 月 19 日受理) 